\section{Stability of Diluted Ketamine Packaged in Glass Vials}

Ketamine hydrochloride for injection is a rapid-acting general anesthetic agent. To avoid an out-of-stock situation for this drug at the desired concentration for administration to patients $(10 \mathrm{mg} / \mathrm{mL})$, the author's institution investigated the chemical stability of a diluted solution of the concentrated formulation $(50 \mathrm{mg} / \mathrm{mL})$, packaged for storage in glass vials. The only difference between the 2 initial formulations was the amount of active pharmaceutical ingredient present.

The chemical stability of ketamine diluted to either 1 $\mathrm{mg} / \mathrm{mL}$ with normal saline ${ }^{1}$ or $10 \mathrm{mg} / \mathrm{mL}$ with sterile water for injection ${ }^{2}$ and packaged in plastic syringes has been studied previously. The more dilute solution was stable for 12 months when stored at $4^{\circ} \mathrm{C}, 25^{\circ} \mathrm{C}$, or $40^{\circ} \mathrm{C}$, whereas the more concentrated solution was stable for 30 days at $25^{\circ} \mathrm{C}$. The purpose of the current study was to determine the chemical stability and physical compatibility of ketamine after dilution of a $50 \mathrm{mg} / \mathrm{mL}$ solution to $10 \mathrm{mg} / \mathrm{mL}$ with sterile water for injection, packaging in glass vials, and storage at room temperature with exposure to light.

A stock solution of ketamine hydrochloride $(50 \mathrm{mg} / \mathrm{mL}$; Sandoz, lot 129290) was aseptically diluted 1 in 5 with sterile water for injection. The resulting solution was then transferred into twenty-one 5-mL glass vials and stored at room temperature with exposure to light. On day 0, 3 vials were collected and frozen at $-70^{\circ} \mathrm{C}$ for analysis at a later date. Similarly, on each of days $7,14,28,56,91$, and 182, 3 vials were collected and frozen at $-70^{\circ} \mathrm{C}$.

On the day of analysis, all of the vials were allowed to thaw for $2 \mathrm{~h}$ at room temperature. Each sample was further diluted by combining $20 \mu \mathrm{L}$ of solution with $100 \mu \mathrm{L}$ of internal standard (phenol, $0.3 \mathrm{mg} / \mathrm{mL}$ ) and $880 \mu \mathrm{L}$ of $25 \%$ acetonitrile solution. A previously validated high-performance liquid chromatography method ${ }^{3}$ was used to assay the samples in duplicate. The $\mathrm{pH}$ of the solutions was monitored with a calibrated $\mathrm{pH}$ meter. Colour and clarity were monitored by the naked eye, with the aid of white and black backgrounds.

After 182 days storage at room temperature, the concentration of all samples remained above $90 \%$ (mean $96.2 \%$; see Table 1). The $\mathrm{pH}$ increased only slightly, from 4.74 to 4.90 . Neither colour nor clarity of the samples changed over time.

On the basis of these results, it can be concluded that ketamine hydrochloride for injection $50 \mathrm{mg} / \mathrm{mL}$, diluted to 10 $\mathrm{mg} / \mathrm{mL}$ with sterile water for injection and packaged in glass vials, may be regarded as chemically stable after storage for up to 182 days at room temperature with exposure to light.
Table 1. Stability of Ketamine Stored in Glass Vials at Room Temperature with Exposure to Light*

\begin{tabular}{lr} 
Study Day & $\begin{array}{c}\% \text { of Initial } \\
\text { Concentration Remaini }\end{array}$ \\
\hline 7 & $99.5 \pm 1.2$ \\
14 & $99.2 \pm 0.9$ \\
28 & $98.8 \pm 0.9$ \\
56 & $99.5 \pm 0.8$ \\
91 & $98.0 \pm 0.3$ \\
182 & $96.2 \pm 0.9$
\end{tabular}

*Nominal original concentration was $10 \mathrm{mg} / \mathrm{mL}$. Observed original concentration (mean \pm standard deviation, based on 3 samples assayed in duplicate $[n=6]$ ) was $9.3 \pm 0.06 \mathrm{mg} / \mathrm{mL}$. tMean \pm standard deviation, based on 3 samples assayed in duplicate $(n=6)$.

\section{References}

1. Stucki MC, Fleury-Souverain S, Sautter AM, Sadeghipour F, Bonnabry P. Development of ready-to-use ketamine hydrochloride syringes for safe use in post-operative pain. Eur J Hosp Pharm Sci. 2008;14(1):14-8.

2. Gupta VD. Stability of ketamine hydrochloride injection after reconstitution in water for injection and storage in 1-mL tuberculin polypropylene syringes for pediatric use. Int J Pharm Compound. 2002;6(4):316-7.

3. Donnelly RF. Physical compatibility and chemical stability of ketamine-morphine mixtures in polypropylene syringes. Can J Hosp Pharm. 2009;62(1):28-33.

Ronald F Donnelly, MSc(Chem), BSc(Pharm)

Product Development Pharmacist

Department of Pharmacy

The Ottawa Hospital, Civic Campus

Ottawa, Ontario

Competing interests: None declared. 